\title{
Symptoms of Attention Deficit, Hyperactivity and Impulsivity in a Sample of Personality Disorder Patients
}

\author{
Laura Aelenei', Dan Prelipceanu'
}

\begin{abstract}
Background: ADHD and personality disorders can show several common clinical characteristics. When evaluating individuals more closely it can be found that there are several specific attention features and also hyperactivity and impulsivity features that can differentiate these diagnostic categories, as well as functionality in different areas of life. Material and methods: In this study a sample of 140 individuals with a personality disorder has been evaluated in order to determine the proportion of symptoms of attention deficit and hyperactivity/impulsivity by using the scale DIVA. Two groups were formed: A - the ADHD group and B - the nonADHD group. The ADHD group has three subgroups depending on the most frequent disabilities (inattentive, hyperactive/impulsive and combined). A global assessment has been made by using the scales CGIs, GAF and WFIRS (Weiss Scale). Results: Average scores have been calculated on the attention and hyperactive/impulsive domain in the two groups and then in the subgroups. The hyperactive/ impulsive domain is better represented in each group. A comparative approach referring to all the groups has been realized. Then, it has been studied the prevalence of the 18 items from the DIVA scale in the groups identified above and the proportions in which they differentiate the two populations. The items $\mathrm{A} 6, \mathrm{~A} 4, \mathrm{H} 1, \mathrm{H} 8$ differentiate best the ADHD and non ADHD patients. The differentiation using the scales CGI, GAF, WFIRS (Weiss Scale) has been studied. Then, the personality disorders in the initial diagnosis have been interpreted. The most frequent personality disorders identified in the ADHD group are: mixed (29\%), antisocial (24\%), borderline (20\%), avoidant (7\%) and histrionic (7\%). Conclusions: The study has been successful in evaluating the difference between ADHD and nonADHD patients not only by differentiating symptoms, but also functionality and the initial diagnostic perspective.
\end{abstract}

Keywords: adult ADHD, personality disorder, DIVA

\section{Rezumat}

Context: ADHD și tulburările de personalitate pot prezenta caracteristici clinice comune. La o evaluare mai atentă a indivizilor se pot evidenția câteva trăsături de deficit atențional și de asemenea de hiperactivitate/impulsivitate care pot diferenția aceste tulburări, ca și disfuncționalitatea în diferite arii ale vieții. Material și metode: În acest studiu un eșantion de 140 de pacienți cu o tulburare de personalitate a fost evaluat pentru a determina proporția simptomelor de deficit atențional și de hiperactivitate/impulsivitate folosind scala DIVA. S-au format două grupuri: A - grupul ADHD și B - grupul nonADHD. Grupul ADHD are trei subgrupuri în funcție de cele mai frecvente deficite (cu inatenție, hiperactivitate/impulsivitate și combinate). O evaluare globală a fost făcută folosind scalele CGIs, GAF și WFIRS (Weiss Scale). Rezultate: Au fost calculate scoruri medii în domeniile atenției și hiperactivității/impulsivi-

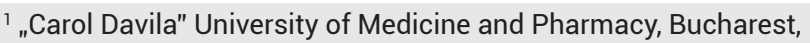
Romania

\section{Corresponding author.}

Laura Aelenei, „Carol Davila" University of Medicine and

Pharmacy, Bucharest, Romania.

E-mail: laura.aelenei.13@gmail.com 
tății la cele două grupuri și apoi la subgrupuri. Domeniul hiperactivitate/ impulsivitate este mai bine reprezentat în fiecare grup. O abordare comparativă la nivelul tuturor grupurilor a fost realizată. Apoi s-a studiat prevalența celor 18 itemi ai scalei DIVA în grupurile identificate mai sus și proporțiile în care aceștia diferențiază cele două populații. Itemii A6, A64, H1, H8 diferențiază cel mai bine pacienții ADHD de cei nonADHD. Diferențierea între grupuri a fost făcută și în functție de scalele CGIs, GAF și WFIRS (Weiss Scale). Apoi au fost interpretate tulburările de personalitate în diagnosticul inițial. Cele mai frecvente tulburări de personalitate la pacienții ADHD au fost cea mixtă (29\%), antisocială (24\%), borderline (20\%), evitantă (7\%) și histrionică (7\%). Concluzii: Studiul a evaluat cu succes diferența dintre pacienții ADHD și nonADHD nu doar prin simptome ci și prin perspectiva diagnostică inițială.

Cuvinte cheie: ADHD la adult, tulburare de personalitate, DIVA

\section{BACKGROUND}

ADHD and personality disorders are known to have clinical presentations that sometimes share different symptoms. Their characteristics are pervasive, relatively stable over the years. This study tries to determine the prevalence of attention deficit and hyperactivity/impulsivity symptoms in a population of individuals with a personality disorder.

ADHD in adults is a disorder that presents symptoms that start early in life, usually observed at the age when the individual is faced with the educational environment. Later on, symptoms persist also in other domains of life, from family life to academic or social environment.

If we refer to personality disorders in general, the diagnostic criteria suggest traits that are persistent and inflexible. Problems in social functioning among people with personality disorder are clinically significant.

There are several descriptions of the main dimensions of personality disorder in studies carried out with different populations. Three or four dimensions are uniformly reported ${ }^{1-5}$, in addition to the well-known five-factor model ${ }^{6,7}$.

The five factors have been defined as openness to experience, conscientiousness, extraversion, agreeableness and neuroticism. Beneath each global factor, there are a number of more specific primary factors ${ }^{8}$.

The categorical description of the various personality disorders is considered poorly specific. A different approach is a dimensional one that refers to core features and enables a more specific characterization of each of the types of the personality disorders.

Some believe that childhood temperaments may become adolescent and adult personality traits, individuals' genetics having a in interaction with the environment ${ }^{9}$. This description enables separation from other disorders with which they are frequently confused, such as attention-deficit/hyperactivity disorder (ADHD) $)^{10}$.

In terms of evolution and prognosis of the individuals, personality disorder has been shown to have an important influence on the outcome of other mental disorders when present as a comorbid condition.

Many studies have approached the correlation between the personality disorders and ADHD.

Miller et al. found that the risk of developing a personality disorder is increased in the individuals with ADHD. In his study he showed that the most frequent were borderline, antisocial, avoidant and narcissistic personality disorders ${ }^{11,12}$.

Some ADHD individuals show an increase in risky behaviours. Antisocial activity and possible detention are also found. A study by Torgerson (2007) found 44\% of ADHD in a population of antisocial personality disorder patients. Roesler (2004) found 45\% ADHD in a population of antisocial personality disorder ${ }^{13}$.

One of the most used instruments that assesses the clinical picture in order to diagnose the ADHD in adults is the DIVA ${ }^{14,15}$.

The scale is based on the DSM IV criteria. It has been developed by J.J.S. Kooij and M.H. Francken and is the first structured Dutch interview for ADHD in adults. The scale has 18 items meant to evaluate the two domains: attention deficit and hyperactivity/impulsivity. The symptoms are evaluated both in childhood and adulthood. Information from family members is considered useful when possible. The presence of possible comorbidities has to be evaluated separately using other instruments.

An ADHD diagnosis according to DSM-IV-TR requires that six or more symptoms from one symptom domain must be present for at least six months, must be inappropriate for the individual's developmental level, interfere with functioning, be evident before seven years of age and be present across settings (e.g. at home and at school). 
DSM-IV-TR defines three diagnostic subtypes based on which symptoms are more frequent: the inattentive subtype (six or more symptoms of inattention), the hyperactive/impulsive subtype (six or more symptoms of hyperactivity/impulsivity) and the combined subtype (six or more from both symptom domains) ${ }^{16}$.

The DIVA consists of 9 items in the attention domain and 9 items in the hyperactive/ impulsive domain, the last being represented by 6 items of hyperactivity and 3 of impulsivity. The ADHD diagnosis is made after the DSM IV classification. This diagnosis is present when more than 6 from 9 criteria from the inattentive or from the hyperactive/impulsive domain are met.

\section{The 18 items are the following:}

A1. Often fails to pay close attention to details, or makes careless mistakes in schoolwork, work or during other activities

A2. Often has difficultly sustaining attention in tasks or play

A3. Often does not seem to listen when spoken to directly

A4. Often does not follow through on instructions and fails to finish schoolwork, chores, or duties in the workplace

A5. Often has difficulty organizing tasks and activities

A6. Often avoids, dislikes, or is reluctant to engage in tasks that require sustained mental effort (such as school of homework)

A7. Often loses things necessary for tasks or activities

A8. Often easily distracted by extraneous stimuli

A9. Often forgetful in daily activities

H/I 1. Often fidgets with hands or feet or squirms in seat

H/I 2. Often leaves seat in classroom or in other situations in which remaining seated is expected

H/I 3. Often runs about or climbs excessively in situations in which it is inappropriate (in adolescents or adults this may be limited to subjective feelings of restlessness)

H/I 4. Often has difficulty playing or engaging in leisure activities

quietly
H/I 5. Is often on the go or often acts as if 'driven by a motor'

H/I 6. Often talks excessively

H/I 7. Often blurts out answers before questions have been completed

H/I 8. Often has difficulty awaiting turn

H/I 9. Often interrupts or intrudes on others ${ }^{16}$.

Symptoms of inattention are characterized several behaviours such as making careless mistakes, forgetfulness, being easily distracted, difficulty with organizing tasks, failure to begin or complete tasks. Symptoms of hyperactivity are characterized by behaviours such as fidgeting with hands or feet, failure to sit still when required, talking excessively and symptoms of impulsivity by interrupting or intruding on others and having difficulty waiting one's turn.

\section{MATERIAL AND METHODS}

The study is a cross-sectional, non-interventional one. In this study 140 individuals were evaluated. The patients have been selected from the following medical facilities: Al. Obregia Hospital (Bucharest), „Eftemie Diamandescu" Balaceanca Hospital (Ilfov County), CETTT Sf. Stelian (Bucharest), CMI Dr. Plavitu Ileana (Bucharest).

The inclusion criteria used have been a previous diagnosis of a personality disorder, the consent to being further investigated. The criteria used in the evaluation have been the DSM IV classification. The exclusion criteria have been the refuse to sign the informed consent, the diagnostic scales left incomplete and acute symptoms at the time of the evaluation.

The 140 individuals have been evaluated using the scale DIVA (The Diagnostic Interview for ADHD in Adults). More of six symptoms in one or both domains (innatentive or hyperactive/impulsive) suggested a positive diagnosis of ADHD. Two groups were formed: $\mathrm{A}$ - the ADHD group and $\mathrm{B}$ - the non ADHD group.

Other scales used in the evaluation have been the CGIs (Clinical Global Impression severity), the GAF Scale (Global Assessment of Functioning), the WFIRS Scale (Weiss Functional Impairment Rating Scale SelfReport, WFIRS-S) ${ }^{17}$.

The demographic and medical data have been collected and inserted into an Excel table.

In this study the 18 items of the DIVA scale have been analysed in the two groups (ADHD and no$\mathrm{nADHD})$ in terms of percentage of response at each 
item, mean number of items in every domain - attention deficit and hyperactivity/impulsivity, the significance of the difference between the two groups.

The ADHD group is divided in three subgroups: predominantly inattentive (ADHD a), combined (ADHD c) and predominantly hyperactive/impulsive (ADHD hi). The items of the DIVA scale have been studied across the three subgroups.

The individuals have been also evaluated using some global clinical scales: the Weiss scale (the total score and the risk score), the CGIs scale and the GAF scale. The scores are evaluated in the two groups.

Another aspect studied has been the frequencies of the types of personality disorders in the initial diagnosis of the individuals evaluated.

There can be identified some limits of the study. The retrospective assessment of a childhood diagnosis can be subjective. It is known that usually the information from the patient can be subjective, the period assessed being several years before. Moreover, the information from the family members is usually absent. Medical records are also difficult to be found.

\section{RESULTS}

\section{The DIVA scale - average scores and item analysis}

\section{a. Average scores in the attention deficit and hyperactive/impulsive domain}

First, it has been determined the mean number of items in the attention deficit domain and then in the hyperactive/impulsive domain in the two groups: ADHD and nonADHD.

The average and SD are $5.20 \pm 1.9776$ number of attention items and respectively $2.25 \pm 1.4731$ for attention deficit domain and $6.66 \pm 1.4766$ number of hyperactivity/impulsivity items and respectively $3.17 \pm 1.4359$ for hyperactivity/impulsivity domain.

As an observation, the average scores in the hyperactivity/impulsivity domain are higher than the attention deficit domain in both the ADHD group and the nonADHD group. This can be interpreted in the way that the initial population is by definition characterized by such traits, like impulsivity and hyperactivity because

Table 1. Average scores in ADHD and nonADHD patients

\begin{tabular}{|c|c|c|c|}
\hline & $\begin{array}{c}\text { ADHD_DSM } \\
\text { IV=Yes }(\mathrm{N}=41)\end{array}$ & $\begin{array}{c}\text { ADHD_DSM } \\
\text { IV=No }(\mathrm{N}=99)\end{array}$ & p-value (Test) \\
\hline DIVA_A_number of items & $\begin{array}{l}5.20 \pm 1.9776 \\
6.0[4.0,6.0] \\
\end{array}$ & $\begin{array}{l}2.25 \pm 1.4731 \\
2.0[1.0,3.0]\end{array}$ & 0.000000 (Independent Samples T Test) \\
\hline DIVA_HI_number of items & $\begin{array}{l}6.66 \pm 1.4766 \\
7.0[6.0,7.5]\end{array}$ & $\begin{array}{l}3.17 \pm 1.4359 \\
3.0[2.0,4.0]\end{array}$ & (Independent Samples T Test) \\
\hline
\end{tabular}

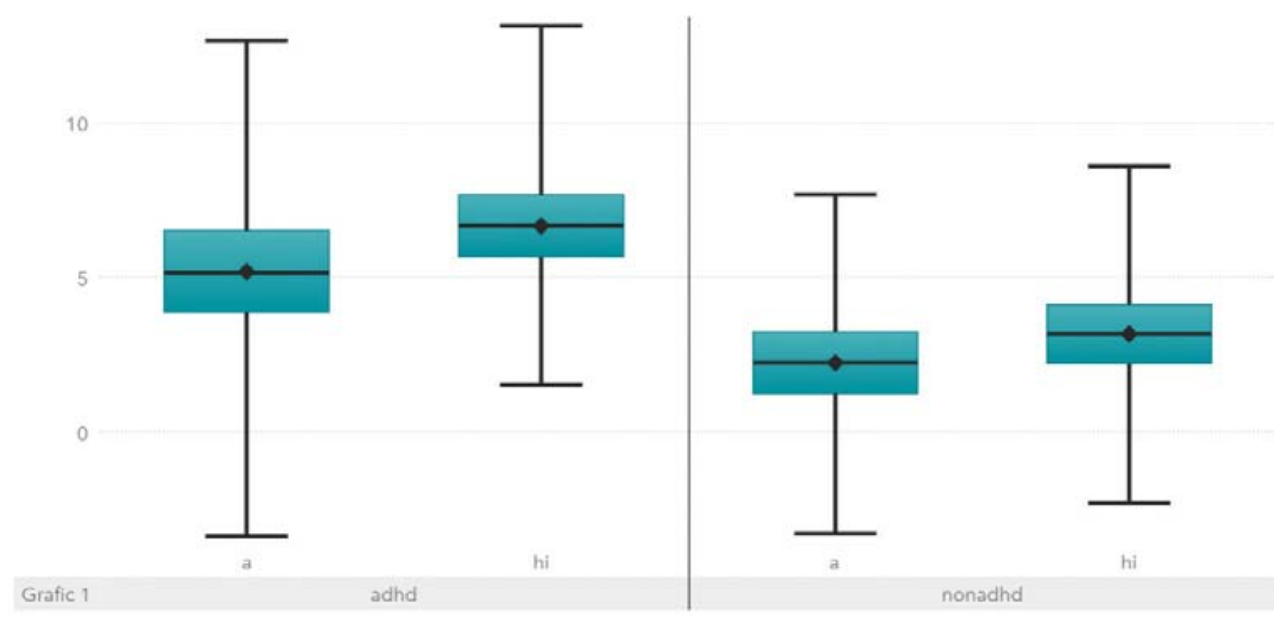

Graphic 1. Average scores in the attention deficit and hyperactive/impulsive domain in the ADHD and nonADHD group. 


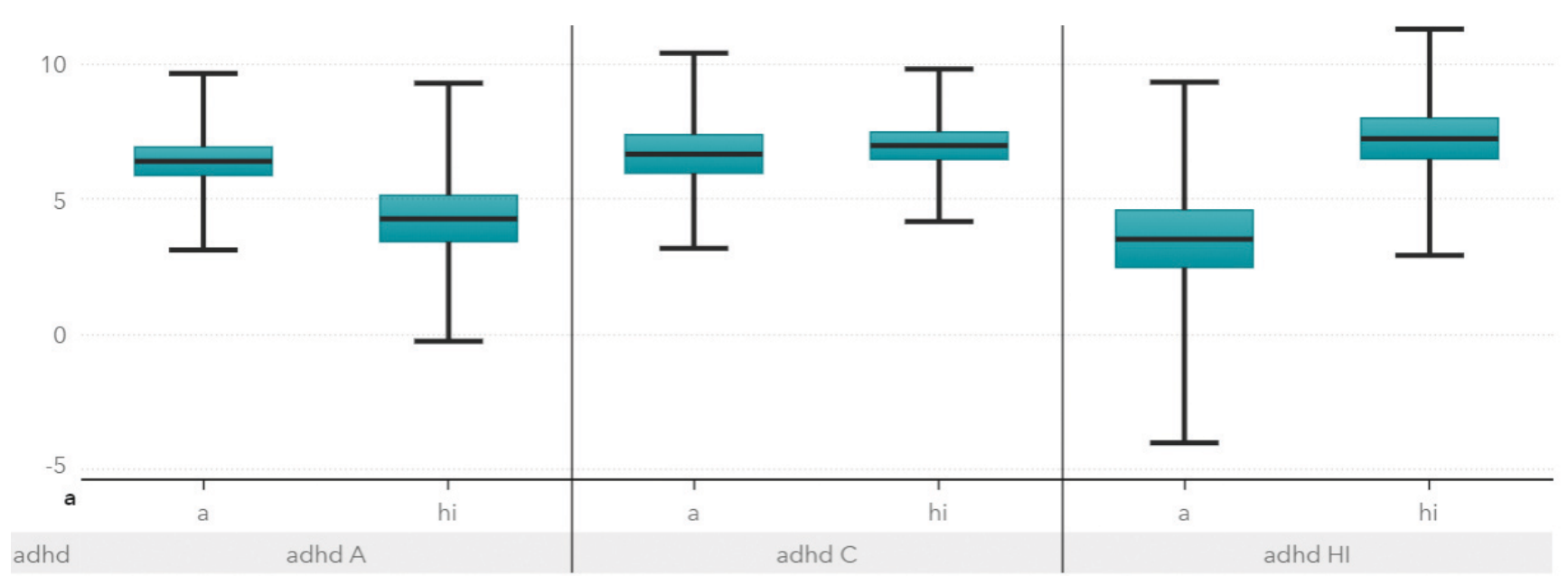

Graphic 2. Average scores in the attention deficit and hyperactive/impulsive domain in the ADHD subgroups: a (predominantly inattentive), c (combined) and hi (hyperactive/impulsive).

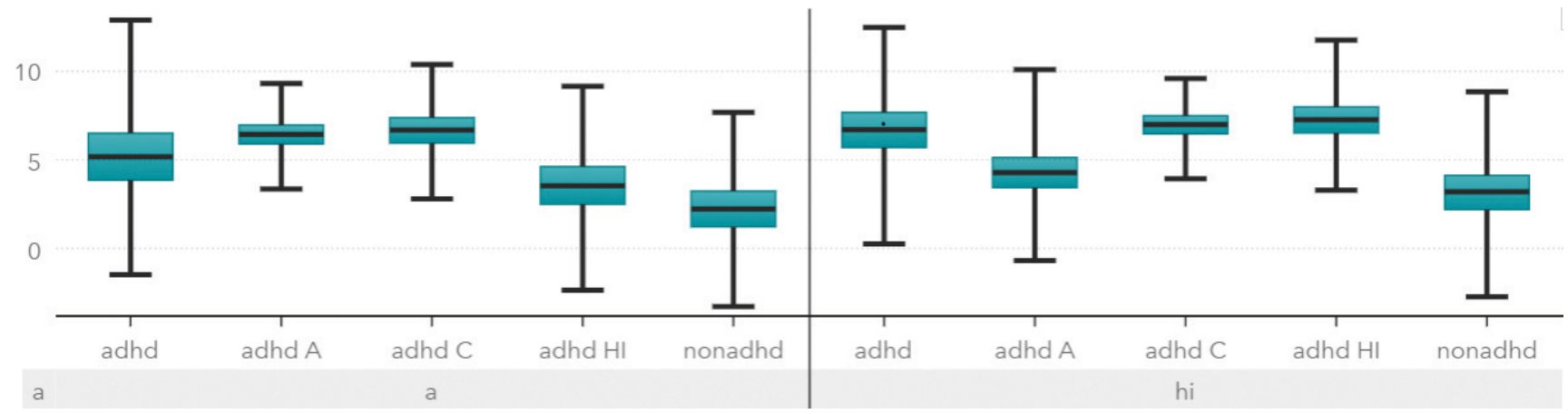

Graphic 3. Average scores - comparative approach.

these are traits common in the individuals with a personality disorder.

The average number of items in the two domains is compared between the two groups and it is shown an important statistical difference ( $p$ value $=0.000000$, Independent Samples T Test) for both domains.

Then, it has been determined the average scores in the attention deficit and hyperactive/impulsive domain in the ADHD subgroups.

A comparative approach referring to all the groups identified by the evaluation using the DIVA Scale is shown below:

\section{b. Item analysis}

The percentage of response at every item (A1-A9, H1-H9) has been illustrated below referring to the ADHD and nonADHD group

The most frequent items in the attention deficit domain are A6, A1, A2 for the ADHD group and A2, A1, A6 for the nonADHD group. So, ADHD patients score higher for items A6, A1, A2 (avoids sustained mental effort, fails to pay close attention to details, difficultly sustaining attention).

The most frequent items in the hyperactivity/impulsivity domain are: $\mathrm{H} 1, \mathrm{H} 3, \mathrm{H} 8$ for the ADHD group and $\mathrm{H} 3, \mathrm{H} 7, \mathrm{H} 8$ for the nonADHD group. So, ADHD patients score high on items H1, H3, H8 (fidgets with hands, subjective feelings of restlessness, difficulty awaiting turn).

Then a comparison between the percentage of response of every item (A1-A9, H1-H9) between the two groups (ADHD and nonADHD) has been made. The statistical test used has been the Pearson Chi-Square. Each comparison generated a $\mathrm{p}$ value shown below.

As observed the difference between the two groups is statistically significant for items A1, A4, A5, A6, A7, A8, A9 and H1- H9. The difference is not important for items A2, A3 (difficultly sustaining attention, does not seem to listen), that means that they are less specific for ADHD symptomatology. 
Laura Aelenei et al.

Table 2. Response at items A1-A9

\begin{tabular}{|l|c|c|c|c|c|c|c|c|c|}
\hline Item & $\mathbf{A 1}$ & $\mathbf{A 2}$ & $\mathbf{A 3}$ & $\mathbf{A 4}$ & $\mathbf{A 5}$ & $\mathbf{A 6}$ & $\mathbf{A 7}$ & $\mathbf{A 8}$ & $\mathbf{A 9}$ \\
\hline $\mathrm{ADHD}$ & 70.7 & 68.3 & 53.7 & 53.7 & 58.5 & 85.4 & 43.9 & 56.1 & 36.6 \\
\hline nonADHD & 41.4 & 51.5 & 38.4 & 18.2 & 23.2 & 39.4 & 22.2 & 23.2 & 16.2 \\
\hline
\end{tabular}

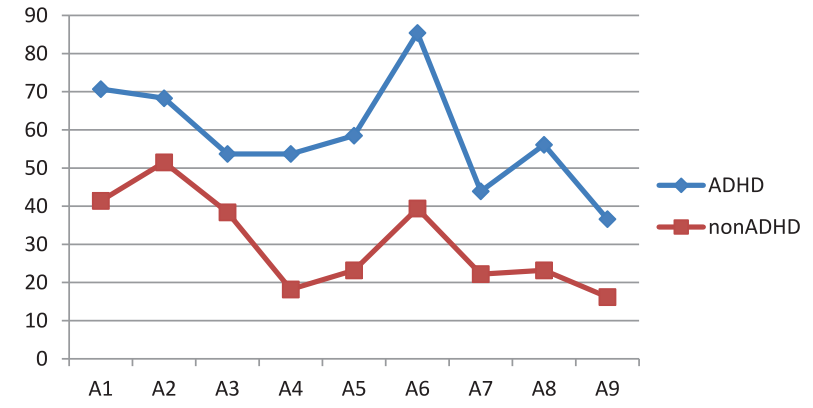

Graphic 4. The percentage of response of items $A 1-A 9$ in ADHD and nonADHD group.

The order of the relevance of the items A1-A9 in terms of the way they can be used in differentiating the $\mathrm{ADHD}$ from the nonADHD patients is: $\mathrm{A} 6, \mathrm{~A} 4, \mathrm{~A} 5$, A8, A1, A9, A7, A2, A3.

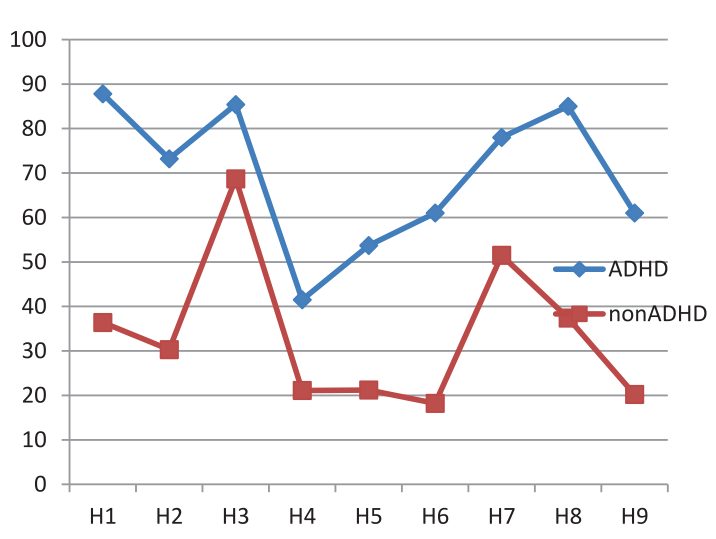

Graphic 5. The percentage of response of items $\mathrm{H} 1-\mathrm{H} 9$ in ADHD and nonADHD group.

Table 3. Response at items $\mathrm{H} 1-\mathrm{H} 9$

\begin{tabular}{|l|c|c|c|c|c|c|c|c|c|}
\hline Item & H1 & H2 & H3 & H4 & H5 & H6 & H7 & H8 & H9 \\
\hline ADHD & 87.8 & 73.2 & 85.4 & 41.5 & 53.7 & 61 & 78 & 85 & 61 \\
\hline nonADHD & 36.4 & 30.3 & 68.7 & 21.1 & 21.2 & 18.2 & 51.5 & 37.4 & 20.2 \\
\hline
\end{tabular}

Table 4. Comparison between the percentage of response of every item (A1-A9, $\mathrm{H} 1-\mathrm{H} 9)$ between the two groups (ADHD and nonADHD)

\begin{tabular}{|c|c|c|c|}
\hline & $\begin{array}{c}\text { ADHD_DSM } \\
\text { IV=Yes }(\mathrm{N}=41)\end{array}$ & $\begin{array}{c}\text { ADHD_DSM } \\
\text { IV=No }(\mathrm{N}=99)\end{array}$ & p-value (Test) \\
\hline$A 1=1$ & $29 / 41(70.7 \%)$ & $41 / 99(41.4 \%)$ & 0.001593 (Pearson Chi-Square) \\
\hline$A 2=1$ & $28 / 41(68.3 \%)$ & $51 / 99(51.5 \%)$ & 0.068471 (Pearson Chi-Square) \\
\hline$A 3=1$ & $22 / 41(53.7 \%)$ & $38 / 99(38.4 \%)$ & 0.096517 (Pearson Chi-Square) \\
\hline$A 4=1$ & $22 / 41(53.7 \%)$ & 18/99 (18.2\%) & 0.000024 (Pearson Chi-Square) \\
\hline$A 5=1$ & $24 / 41(58.5 \%)$ & $23 / 99(23.2 \%)$ & 0.000057 (Pearson Chi-Square) \\
\hline$A 6=1$ & $35 / 41(85.4 \%)$ & $39 / 99(39.4 \%)$ & 0.000001 (Pearson Chi-Square) \\
\hline$A 7=1$ & $18 / 41(43.9 \%)$ & $22 / 99(22.2 \%)$ & 0.009764 (Pearson Chi-Square) \\
\hline$A 8=1$ & $23 / 41(56.1 \%)$ & 23/99 (23.2\%) & 0.000165 (Pearson Chi-Square) \\
\hline$A 9=1$ & $15 / 41(36.6 \%)$ & $16 / 99(16.2 \%)$ & 0.008083 (Pearson Chi-Square) \\
\hline$H I 1=1$ & $36 / 41(87.8 \%)$ & $36 / 99(36.4 \%)$ & 0.000000 (Pearson Chi-Square) \\
\hline $\mathrm{HI} 2=1$ & $30 / 41(73.2 \%)$ & $30 / 99(30.3 \%)$ & 0.000003 (Pearson Chi-Square) \\
\hline $\mathrm{HI}=1$ & $35 / 41(85.4 \%)$ & $68 / 99(68.7 \%)$ & 0.041682 (Pearson Chi-Square) \\
\hline $\mathrm{HI} 4=1$ & $17 / 41(41.5 \%)$ & $12 / 99(21.1 \%)$ & 0.000097 (Pearson Chi-Square) \\
\hline $\mathrm{HI} 5=1$ & $22 / 41(53.7 \%)$ & $21 / 99(21.2 \%)$ & 0.000152 (Pearson Chi-Square) \\
\hline$H I 6=1$ & $25 / 41(61.0 \%)$ & $18 / 99(18.2 \%)$ & 0.000001 (Pearson Chi-Square) \\
\hline $\mathrm{HI}=1$ & $32 / 41(78.0 \%)$ & $51 / 99(51.5 \%)$ & 0.003638 (Pearson Chi-Square) \\
\hline $\mathrm{HI} 8=1$ & $35 / 41(85.4 \%)$ & $37 / 99(37.4 \%)$ & 0.000000 (Pearson Chi-Square) \\
\hline $\mathrm{HI}=1$ & $25 / 41(61.0 \%)$ & $20 / 99(20.2 \%)$ & 0.000003 (Pearson Chi-Square) \\
\hline
\end{tabular}


The most relevant in differentiating the two pathologies are items A6 (avoids tasks that require sustained mental effort), A4 (does not follow through on instructions and fails to finish duties).

The less useful items for differentiation but still statistically significant are A9 (being forgetful), A7 (losing things).

It can be observed that item A6 (avoids tasks that require sustained mental effort) is both the most frequent but also the most useful in differentiating the two subgroups.

Likewise, in the hyperactivity/impulsivity domain, the order of the items in terms of the way they can be used in differentiating the ADHD from the nonADHD patients is: $\mathrm{H} 1, \mathrm{H} 8, \mathrm{H} 6, \mathrm{H} 2, \mathrm{H} 9, \mathrm{H} 4, \mathrm{H} 5$, $\mathrm{H} 7, \mathrm{H} 3$.

The most relevant in differentiating the two pathologies are items $\mathrm{H} 1$ (fidgets with hands or feet), H8 (difficulty awaiting turn).

The less useful items for differentiation $\mathrm{H} 7$ (answers before questions have been completed), H3 (restlessness).

It can be observed that the item H1 (fidgets with hands or feet) is the most frequent but also the best to differentiate the two subgroups.

\section{The ADHD subgroups - ADHD a, ADHD c, ADHD hi}

The percentage of response at every item has been studied across the three subgroups (ADHD a, ADHD c, ADHD hi). The results have been graphically illustrated.

The results from the statistical analysis show that the subgroups can be differentiated by several items. The combined type can be differentiated from the hyperactive/impulsive type by items A2 and A5 (difficultly sustaining attention in tasks or play and difficulty organizing tasks) and the inattentive subgroup from the hyperactive/impulsive subgroup by items $\mathrm{H} 5, \mathrm{H} 6$, H9 (acts as if 'driven by a motor', talks excessively, interrupts others).

\section{CGIs scale, GAF scale and WFIRS (Weiss) scale}

The scores of the Weiss scale, CGIs scale and GAF scale have been analysed between the two groups.

The average values of the scales CGI, GAF, Weiss (total score and risk domain) have been calculated. They are shown below. The differences between the two groups - ADHD and nonADHD - have been studied using the Independent Samples T Test.

The average values of the CGI and GAF scale do not differ statistically between the ADHD and nonADHD patients ( $\mathrm{p} \_$value $=0.807587$ for CGI and $\mathrm{p}$ value $=0.206424$ for GAF). That means that the global evaluation of the patients using nonspecific clinical scales does not discriminate between the ADHD pathology and the personality disorders.

The average values of the Weiss Functional Impairment Rating scale (WFIRS) differ statistically betwe-

Table 5. Response at every item across the three subgroups

\begin{tabular}{|l|c|c|c|c|}
\hline & Subtip_ADHD & Subtip_ADHD & Subtip_ADHD & \multirow{2}{*}{ p-value (Test) } \\
\cline { 2 - 4 } & IV=A (N=7) & IV=C (N=15) & $57.90 \%$ & 0.228279 \\
\hline A1 & $85.70 \%$ & $80.00 \%$ & $47.40 \%$ & 0.010001 \\
\hline A2 & $71.70 \%$ & $93.30 \%$ & $36.80 \%$ & 0.097685 \\
\hline A3 & $57.10 \%$ & $73.30 \%$ & $36.80 \%$ & 0.097685 \\
\hline A4 & $57.10 \%$ & $73.30 \%$ & $31.60 \%$ & 0.000545 \\
\hline A5 & $57.10 \%$ & $93.30 \%$ & $89.50 \%$ & 0.5503 \\
\hline A6 & $71.40 \%$ & $86.70 \%$ & $26.30 \%$ & 0.101518 \\
\hline A7 & $57.10 \%$ & $60.00 \%$ & $42.10 \%$ & 0.109105 \\
\hline A8 & $85.70 \%$ & $60.00 \%$ & $36.80 \%$ & 0.305307 \\
\hline A9 & $14.30 \%$ & $46.70 \%$ & $94.70 \%$ & 0.299114 \\
\hline HI1 & $71.40 \%$ & $86.70 \%$ & $84.20 \%$ & 0.292722 \\
\hline HI2 & $57.10 \%$ & $66.70 \%$ & $84.20 \%$ & 0.398601 \\
\hline HI3 & $71.40 \%$ & $93.30 \%$ & $26.30 \%$ & 0.043605 \\
\hline HI4 & $28.60 \%$ & $66.70 \%$ & $68.40 \%$ & 0.039753 \\
\hline HI5 & $14.30 \%$ & $53.30 \%$ & $78.90 \%$ & 0.009291 \\
\hline HI6 & $14.30 \%$ & $60.00 \%$ & $84.20 \%$ & 0.66752 \\
\hline HI7 & $71.40 \%$ & $73.30 \%$ & $89.50 \%$ & 0.108502 \\
\hline HI8 & $57.10 \%$ & $93.30 \%$ & $78.90 \%$ & 0.009291 \\
\hline HI9 & $14.30 \%$ & $60.00 \%$ & & \\
\hline
\end{tabular}




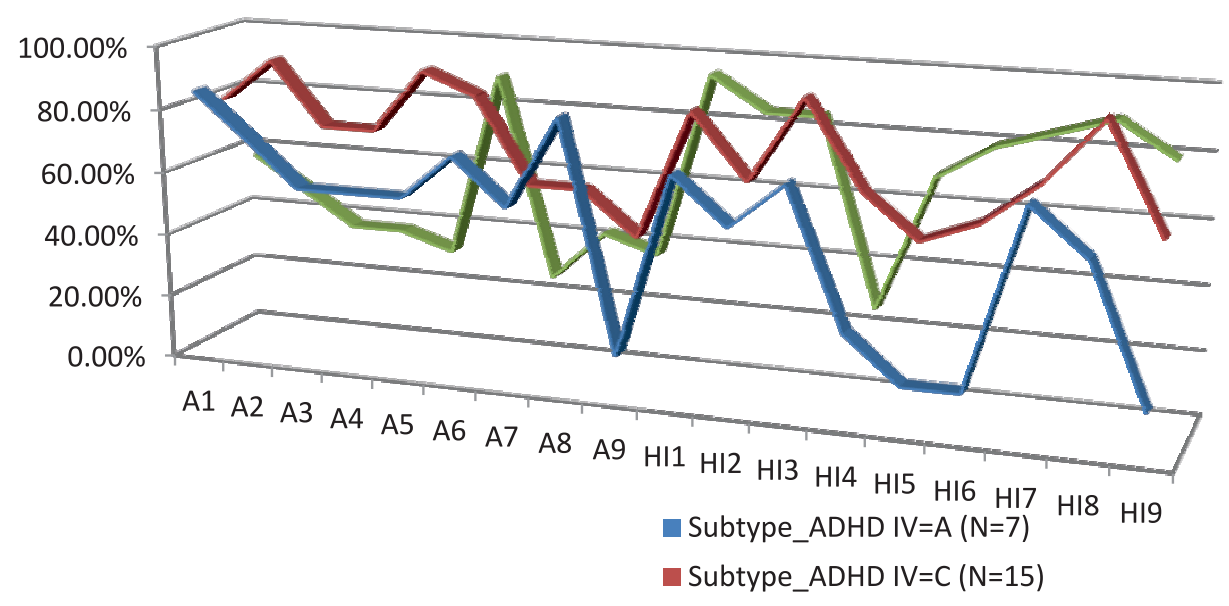

Graphic 6. The percentage of response at every item across the three subgroups (ADHD a, ADHD c, ADHD hi).

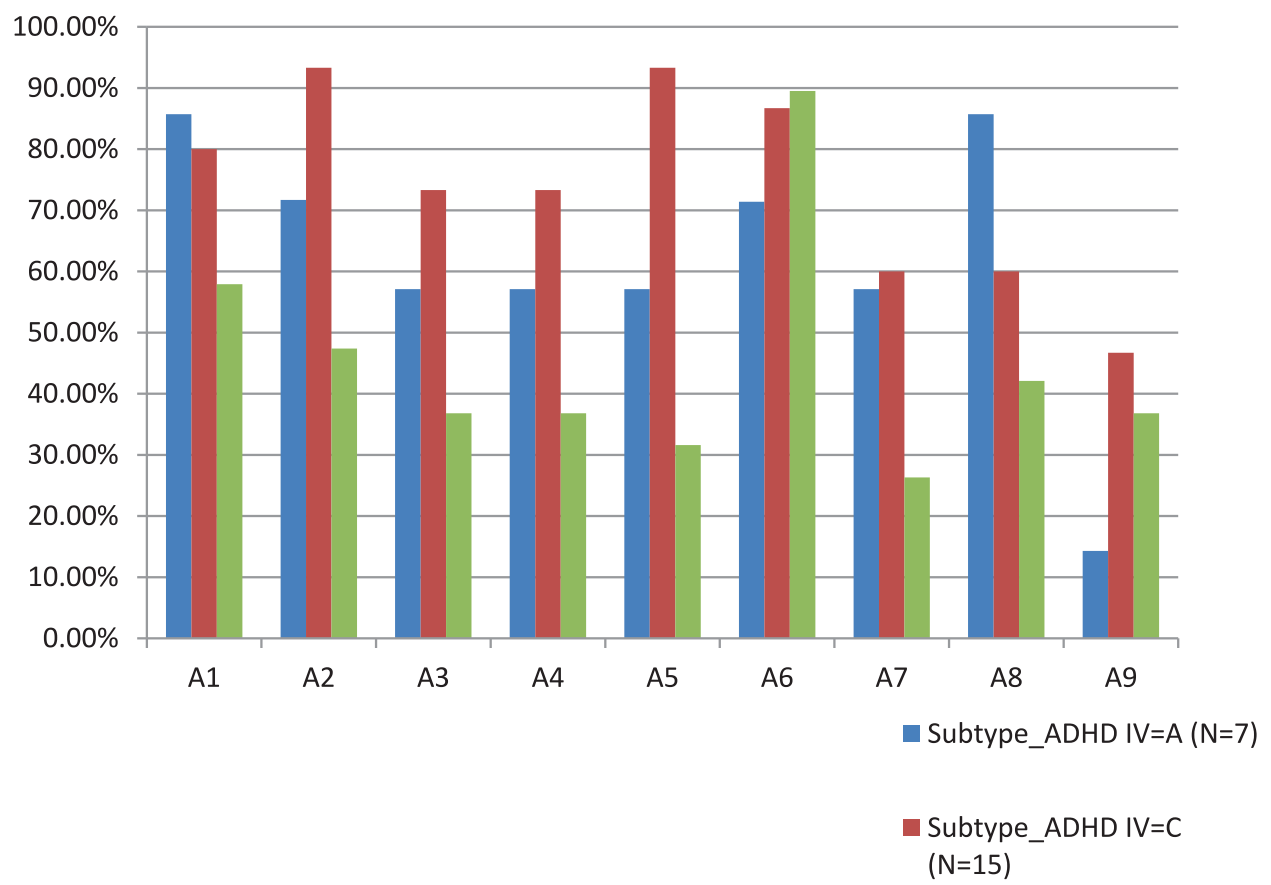

Graphic 7. The attention domain in the three subgroups.

en the two groups ( $\mathrm{p}$ value $=0.002912$ for Weiss scale total score, 0.031711 for Weiss risk. This result shows that the Weiss scale is an instrument that can discriminate between the two pathologies especially the total score. The risk score can also differentiate them but the $\mathrm{p}$ value is smaller in this case, meaning that the difference is smaller than the global evaluation in all the domains, easy to understand taking into account that the personality disorder category is in itself associated with risky behavior.

\section{The personality disorders in the initial diagnosis}

The frequencies of the types of personality disorders in the initial diagnosis of the individuals evaluated has been determined and analysed across the two groups 


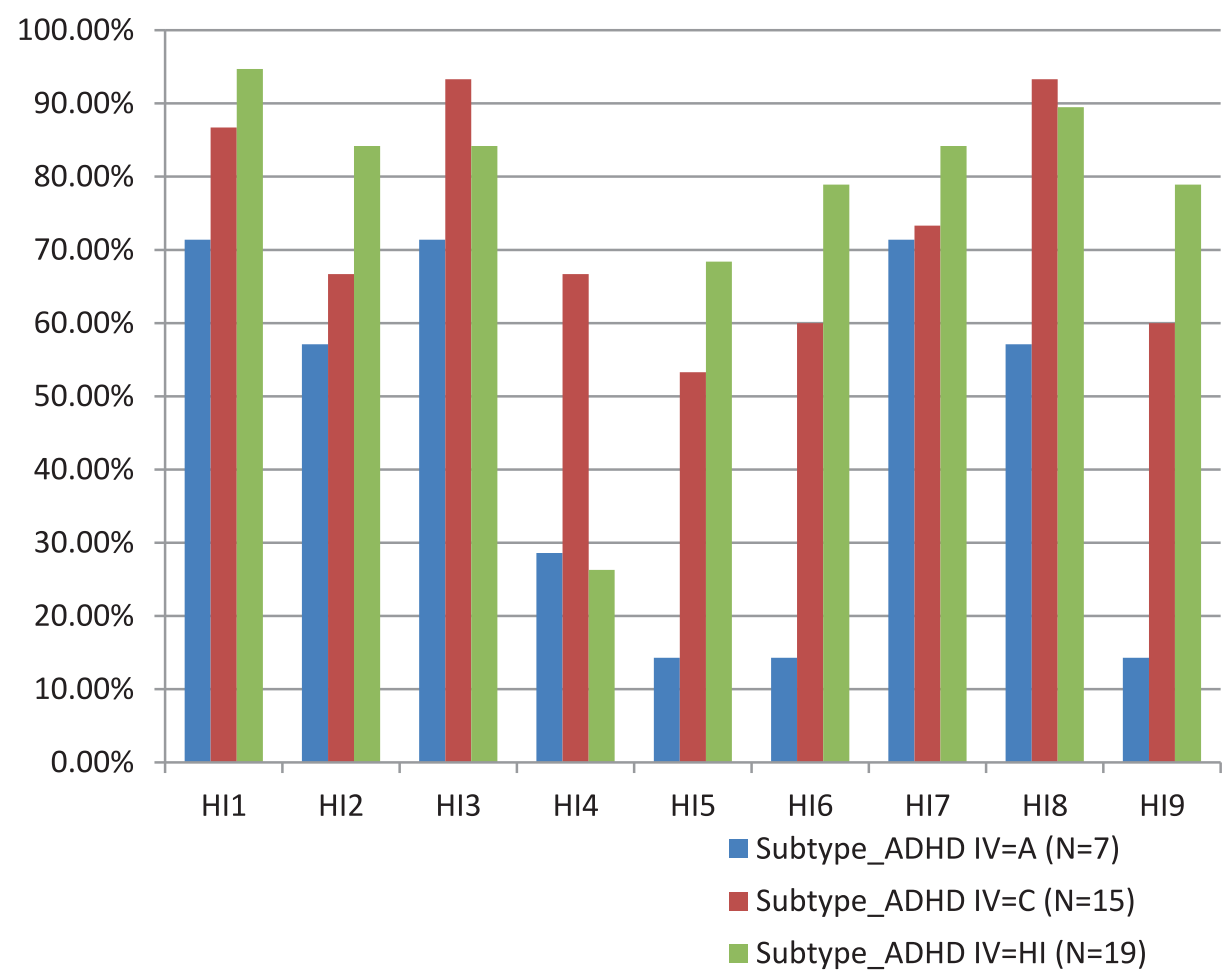

Graphic 8. The hyperactivity/impulsivity domain in the three subgroups.

\begin{tabular}{|c|c|c|c|}
\hline cgi & $\begin{array}{l}3.95 \pm 1.0476 \\
4.0[3.0,5.0]\end{array}$ & $\begin{array}{l}4.00 \pm 1.0879 \\
4.0[3.0,5.0]\end{array}$ & 0.807587 (Independent Samples T Test) \\
\hline gaf & $\begin{array}{l}63.41 \pm 16.4483 \\
60.0[50.0,80.0]\end{array}$ & $\begin{array}{l}59.60 \pm 16.0940 \\
55.0[50.0,70.0]\end{array}$ & 0.206424 (Independent Samples T Test) \\
\hline weiss_total & $\begin{array}{c}80.15 \pm 28.6256 \\
89.0[60.5,102.5]\end{array}$ & $\begin{array}{l}64.05 \pm 28.5815 \\
62.0[39.0,92.0]\end{array}$ & 0.002912 (Independent Samples T Test) \\
\hline weiss_risk & $\begin{array}{c}15.61 \pm 9.0273 \\
16.0[8.5,20.0]\end{array}$ & $\begin{array}{c}11.95 \pm 9.1041 \\
10.0[4.0,20.0]\end{array}$ & 0.031711 (Independent Samples T Test) \\
\hline
\end{tabular}

(ADHD and nonADHD). There have been also graphically illustrated.

\section{CONCLUSIONS}

The prevalence of response to the items of the DIVA scale from the two domains (A1-A9 and H1-H9) have been determined in the ADHD and nonADHD population and the difference between the two groups has been statistically evaluated. The average scores that have been calculated show the way the symptoms vary across the selected groups and subgroups.

The average scores in the hyperactivity/impulsivity domain is higher than the attention deficit domain in both the ADHD group and the nonADHD group. A possible explanation is that we initially selected patients from a category that has as core features the impulsivity, the low frustration tolerance.

The most frequent items in the attention deficit domain are A6, A1, A2 for the ADHD group and A2, A1, A6 for the nonADHD group.

The most frequent items in the hyperactivity/impulsivity domain are: $\mathrm{H} 1, \mathrm{H} 3, \mathrm{H} 8$ for the ADHD group and $\mathrm{H} 3, \mathrm{H} 7, \mathrm{H} 8$ for the nonADHD group.

From the attention domain the most relevant in differentiating the two pathologies are items A6 (avoids tasks that require sustained mental effort), A4 (does 


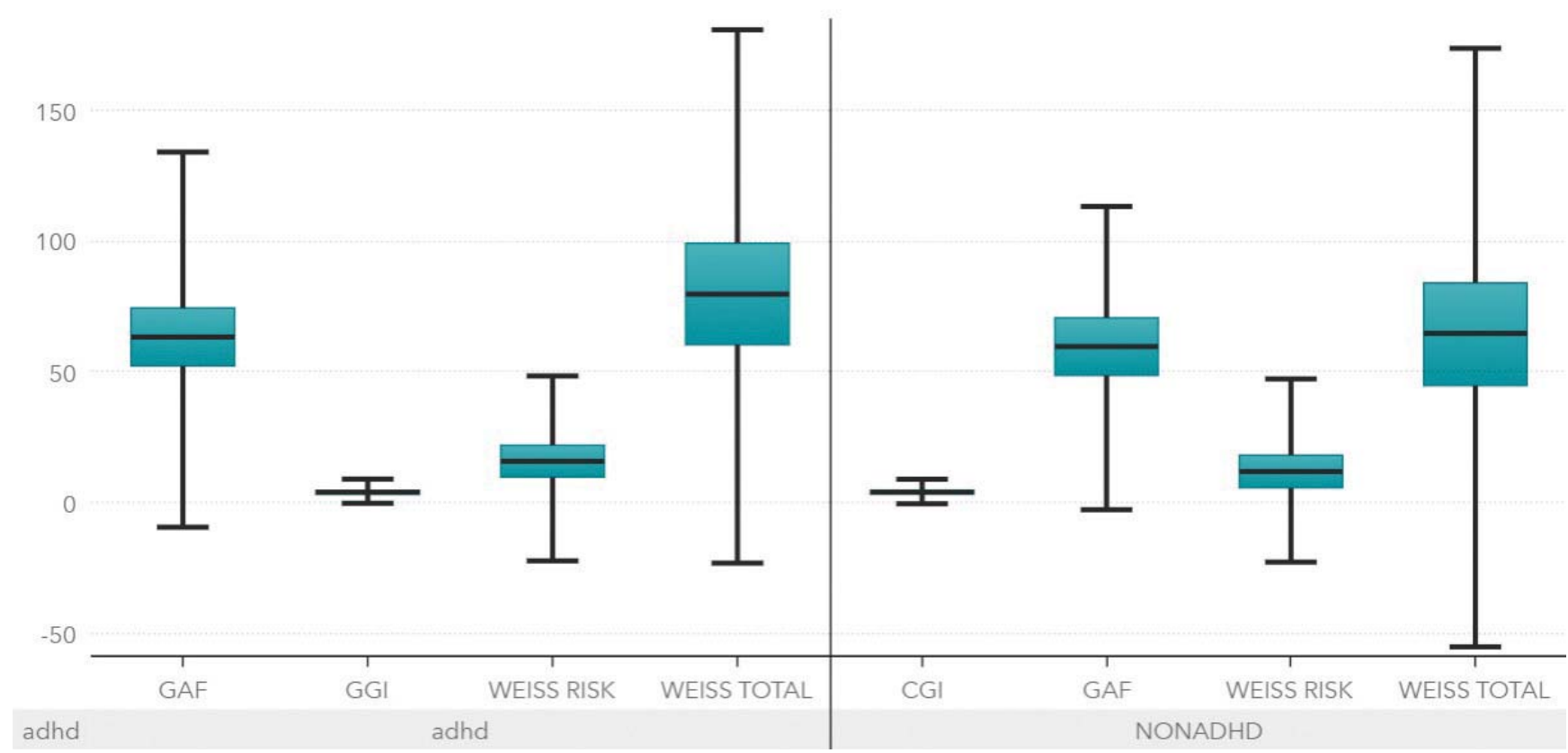

Graphic 9. The average values of the scales CGI, GAF, Weiss Scale (WFIRS - total score and risk domain).

\begin{tabular}{|c|c|c|}
\hline & $\begin{array}{c}\text { ADHD_DSM } \\
\text { IV=yes }(\mathrm{N}=41)\end{array}$ & $\begin{array}{c}\text { ADHD_DSM } \\
\text { IV=no (N=99) }\end{array}$ \\
\hline antisocial & $10 / 41(24.4 \%)$ & $18 / 99(18.2 \%)$ \\
\hline borderline & $8 / 41(19.5 \%)$ & 11/99 (11.1\%) \\
\hline dependent & $0 / 41(0.0 \%)$ & $2 / 99(2.0 \%)$ \\
\hline avoidant & $3 / 41(7.3 \%)$ & $3 / 99(3.0 \%)$ \\
\hline histrionic & $3 / 41(7.3 \%)$ & 9/99 (9.1\%) \\
\hline mixed & $12 / 41(29.3 \%)$ & $52 / 99(52.5 \%)$ \\
\hline narcissistic & $1 / 41(2.4 \%)$ & $1 / 99(1.0 \%)$ \\
\hline obsessive-compulsive & $2 / 41(4.9 \%)$ & $1 / 99(1.0 \%)$ \\
\hline paranoid & $2 / 41(4.9 \%)$ & $0 / 99(0.0 \%)$ \\
\hline schizoid & $0 / 41(0.0 \%)$ & $1 / 99(1.0 \%)$ \\
\hline schizotypal & $0 / 41(0.0 \%)$ & $1 / 99(1.0 \%)$ \\
\hline
\end{tabular}

not follow through on instructions and fails to finish duties).

From the hyperactive/impulsive domain the most relevant in differentiating the two pathologies are items H1 (fidgets with hands or feet), H8 (difficulty awaiting turn).

The ADHD group can be divided in 3 subgroups. They can be also differentiated by several items of the DIVA scale.

The average values of the CGI and GAF scale do not differ between the two groups.

The average values of the Weiss scale differ statistically between the two groups. There is a significant sta-

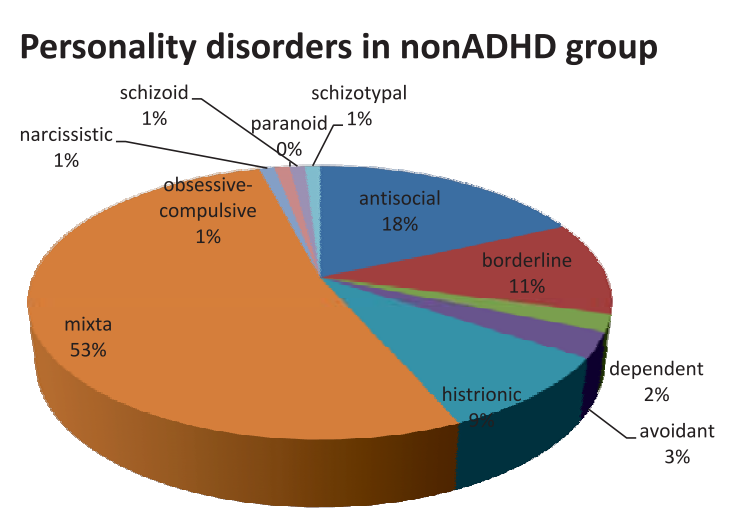

Graphic 10.

\section{Personality disorders in ADHD group}

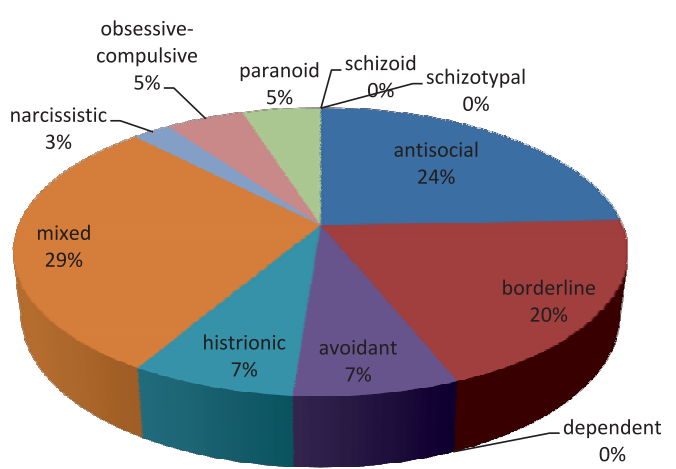

Graphic 11. 


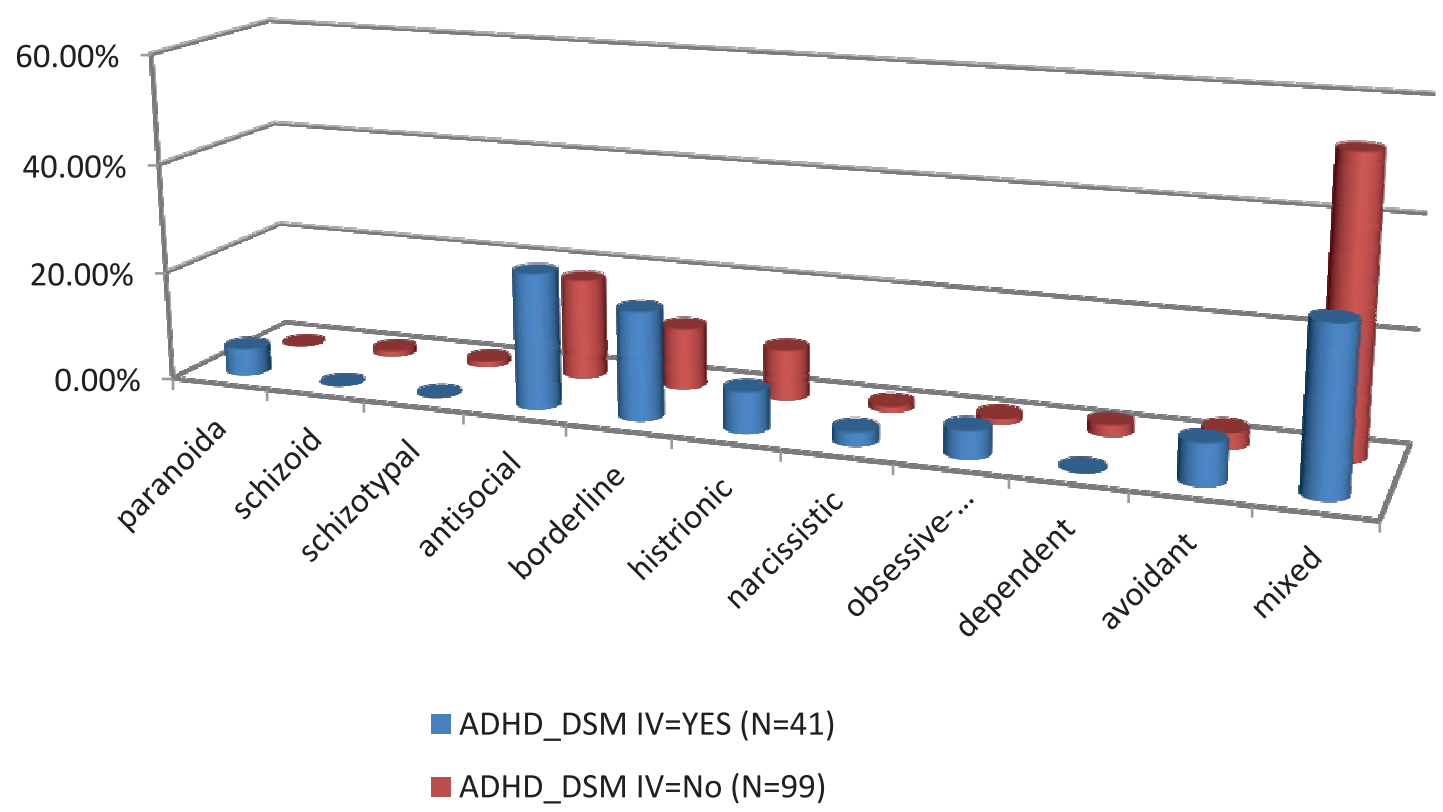

Graphic 12. The personality disorders in the initial diagnosis - comparative approach.

tistical evidence for both the total score and the risky behaviour domain.

The most frequent personality disorders identified in the ADHD group are: mixed (29\%), antisocial (24\%), borderline (20\%), avoidant (7\%) and histrionic (7\%). In the nonADHD group the most frequent personality disorders are mixed (55\%), antisocial (18\%), borderline (11\%), histrionic (9\%) and avoidant (3\%). We notice that the types found more frequent are the same in the two groups, the proportion being different. The best represented are the cluster B types, probably because the individuals from this diagnosis category would seek medical assistance more frequently.

The study evaluated a sample of patients initially diagnosed with a personality disorder. By using specific scales that test the domains of attention, hyperactivity and impulsivity, it has been found that a proportion of the patients can be reconsidered as ADHD patients. So, at a closer and more attentive approach, characteristics of the personality can be reframed in another more specific syndrome that starts actually from childhood and go further in the adult life. This perspective offers the clinician other clinical and therapeutic opportunities that are useful in the psychiatric practice.

\section{Compliance with ethics requirements:}

The authors declare no conflict of interest regarding this article.

The authors declare that all the procedures and experiments of this study respect the ethical standards in the Helsinki Declaration of 1975, as revised in 2008(5), as well as the national law. Informed consent was obtained from all the patients included in the study.

\section{References}

1. Moukhtarian TR, Mintah RS, Moran P, Asherson P. Emotion dysregulation in attention-deficit/hyperactivity disorder and borderline personality disorder. BMC. 2018.

2. Tyrer $\mathrm{P}$, Alexander J. Classification of personality disorder. $\mathrm{Br} \mathrm{J}$ Psychiatry. 1979;135:163-167.

3. Livesley WJ. A systematic approach to the delineation of personality disorders. Am J Psychiatry. 1987;144:772-777.

4. Mulder RT, Joyce PR. Temperament and the structure of personality disorder symptoms. Psychol Med. 1997;27:99-106.

5. Fossati A, Maffei C, Bagnato M. Patterns of covariation of DSMIV personality disorders in a mixed psychiatric sample. Compr Psychiatry. 2000;41:206-215.

6. Costa PT, McCrae RR. Personality disorders and the five-factor model of personality. J Person Disord. 1990;4:362-371. 
7. Widiger TA, Mullins-Sweatt SN. Five-factor model of personality disorder: a proposal for DSM-V. Ann Rev Clin Psychol. 2009; 5:197-220.

8. DeYoung C. G., Quilty L. C., Peterson J. B. Between facets and domain: 10 aspects of the Big Five. J. Pers. Soc. Psychol. 2007; 93:880-896. doi:10.1037/0022-3514.93.5.880.

9. Rothbart M. K, Ahadi S. A., Evans D. E. Temperament and personality: Origins and outcomes. Journal of Personality and Social Psychology. 2000. 78(1): 122-135. doi:10.1037/00223514.78.1.122

10. Philipsen A, Limberger MF, Lieb K. Attention-deficit hyperactivity disorder as a potentially aggravating factor in borderline personality disorder. Br J Psychiatry. 2008;192:118-123.

11. Miller C, Flory J., Miller S. Childhood ADHD and the Emergence of Personality Disorders in Adolescence: A Prospective Followup Study. J Clin Psychiatry. 2008 September; 69(9): 1477-1484

12. Oliva F, Bramante S, Portigliatti A et al. Personality traits and disorders among adult ADHD Patients: Is borderline personality disorder as common as we expect? European Psychiatry. 2017, april, vol 41 suppl

13. Torgersen T, Gjervan B. ADHD in adults: A study of clinical characteristics, impairment and comorbidity. Nord J Psychiatry 2006.
14. Kooij JJS, Boonstra AM, Willemsen-Swinkels SHN. Reliability, validity, and utility of instruments or self-report and informant report regarding symptoms of ADHD in adult patients. J Atten Disorders. 2008; 11(4):445-458.

15. Adler L, Cohen J. Diagnosis and evaluation of adults with ADHD. Psychiatr Clin North Am. 2004; 27(2):187-201.

16. American Psychiatric Association. Diagnostic and Statistical Manual of Mental Disorders. 4 ed. Washington, DC: American Psychiatric Publishing, 2000

17. Weiss M, Functional Impairment in ADHD. In: Adler LA, Spencer TJ, Wilens TE. Attention-Deficit Hyperactivity Disorder in Adults and Children, Cambridge University Press, 2015, 42-52.
Abbreviations
GAF
CGI
Global Assessement of Functioning
WFIRS Clinical Global Impression
DIVA
Weiss Functional Impairment Rating Scale Diagnostic Interview for ADHD in adults 